\title{
Konserwacja kościoła pw. św. Jana Apostoła i Ewangelisty na Harendzie w ujęciu koncepcji „żywego dziedzictwa”
}

\author{
Katarzyna Banasik-Petri \\ https://orcid.org/0000-0002-2375-920X \\ kpetri@afm.edu.pl \\ Wydziat Architektury i Sztuk Pięknych, Krakowska Akademia AFM w Krakowie
}

\section{Ewa Tymcik}

https://orcid.org/0000-0002-3339-6326

tymciu@op.pl

Akademia Sztuk Pięknych w Krakowie

\section{Maria Petri \\ https://orcid.org/0000-0003-3010-3222 \\ mwkpetri@gmail.com}

MA Heritage Management Queen Mary University of London

\begin{abstract}
Streszczenie: Celem artykułu jest syntetyczne przedstawienie programu konserwacji kościoła pw. św. Jana Apostoła i Ewangelisty na Harendzie w Zakopanem w kontekście współczesnych tendencji konserwatorskich związanych z ochroną dziedzictwa kulturowego. Artykuł ma na celu analizę zabytkowego kościoła ze szczególnym uwzględnieniem takich aspektów, jak jego historia, elementy formalno-konstrukcyjne, oraz proponowany program planowanej konserwacji, w myśl szeroko pojętej koncepcji "żywego dziedzictwa". Metoda badawcza polegała na przeglądzie i analizie literatury tematu oraz na autorskich badaniach architektonicznych, w tym inwentaryzacyjnych pracach terenowych.
\end{abstract}

Słowa kluczowe: żywe dziedzictwo, architektura drewniana, konserwacja architektury drewnianej, dziedzictwo kulturowe, kościół pw. św. Jana Apostoła i Ewangelisty na Harendzie

Wstęp

Podróżny łaknie autentyczności - którą skądinąd też sobie wcześniej jakoś wyobrazit. A także oryginalności i rodzimości tego, co jedzie ogląać. I czasem znajduje je $w$ dawnej lokalnej architekturze, w założeniach urbanistycznych, w trudno nieraz uchwytnym tle kulturowym. Znajduje je też w miejscowych muzeach i skansenach (jeżeli takie tam istnieja) - niezależnie od tego, że umieszczone w nich wytwory kultury zostaty wyrwane z autentycznego kontekstu1.

Marian Golka 
Kościół pw. św. Jana Apostoła i Ewangelisty na Harendzie w Zakopanem to przykład obiektu o bogatej historii, mocno związanego z oddolnymi inicjatywami, zarówno w kwestii jego budowy w Zakrzowie, jak i przenosin na Harendę czy procesu renowacji. Od 1951 widnieje w rejestrze zabytków² ${ }^{2}$ jest również wpisany na listę Szlaku Architektury Drewnianej w Małopolsce. Jest doskonałym przykładem, jak renomowany obiekt historyczny może stać się elementem znacząco związanym z lokalną społecznością, a nie tylko ściśle chronionym i wyalienowanym bytem muzealnym. W artykule zostanie zatem podjęta zarówno tematyka techniczno-estetycznych jak i społecznych wyzwań konserwatorskich, w oparciu o wyjątkową historię kościoła. Wprowadzone zostanie pojęcie „żywego dziedzictwa”, które, choć stosunkowo nowe, w przypadku polskiej drewnianej architektury sakralnej wydaje się być aktualne i trafione.

\section{Koncepcja „żywego dziedzictwa”}

Według loannisa Pouliosa ${ }^{3}$, uznanego teoretyka i praktyka w zakresie współczesnych teorii konserwacji, podejście do tejże można podzielić na trzy główne kategorie, opierające się na wartościowaniu poszczególnych elementów dziedzictwa i od tego uzależniające podejmowane działania konserwatorskie. Wymieniane jest podejście "material-based" („oparte na materiale") uznające oryginalną tkankę historyczną jako najwyższą wartość, podejście "values-based” („oparte na wartościach”) polegające przede wszystkim na ochronie niematerialnych zasobów - tradycji czy zwyczajów i wierzeń, oraz podejście "living heritage”“4 (żywe dziedzictwo").

Podejście "oparte na materiale" jest najbardziej powszechne i oczywiste. Laurajane Smith ${ }^{5}$ nazywa je „autoryzowanym dyskursem o dziedzictwie" ${ }^{\prime \prime}$. Metoda ta koncentruje się przede wszystkim na ochronie zachowanej historycznej tkanki z zaangażowaniem specjalistów i to właśnie ona była impulsem, który położył podwaliny pod dyscyplinę konserwacji na przełomie XIX i XX wieku. Podejście "oparte na materiale" zostało również potwierdzone w Karcie Weneckiej z 1964 r., jednym z najważniejszych dokumentów dotyczących konserwacji i restauracji.

Podejście "oparte na wartościach", stawia w centrum uwagi nie samą historyczną tkankę, ale raczej historię, zwyczaje i inne niematerialne, choć równie ważne artefakty historyczne (Karta Burra z australijskiego ICOMOS 1999) ${ }^{7}$. W 2003 roku UNESCO przyjęło Konwencję o ochronie niematerialnego dziedzictwa kulturowego, uwzględniającą właśnie podejście "oparte o wartości”"

Koncepcja "żywego dziedzictwa” jest najnowszym podejściem opisywanym w standardach konserwatorskich w ciągu ostatnich 20 lat $^{9}$. „Żywe dziedzictwo” koncentruje się na podtrzymaniu ciągłości lub odtworzeniu pierwotnej funkcji miejsca historycznego oraz przekazaniu go społeczności zamieszkującej lub użytkującej daną

2 Decyzją Wydziału Kultury i Sztuki - Oddział Muzeów i Ochrony Zabytków obiekt został wpisany do rejestru zabytków pod nr A-269 z 14.07.1951[A-1112/M].

3 loannis Poulios prowadził prace badawcze nad ochroną dziedzictwa na University College London, zwieńczone tamże pracą doktorską. Uczęszczał na kursy Master of Business Administration (Magisterskie Studia Menedżerskie) z zakresu strategii biznesowej i zarządzania w London Business School oraz współpracował jako konsultant ds. dziedzictwa Międzynarodowym Centrum Badań nad Ochroną i Konserwacją Dziedzictwa Kulturowego (ICCROM) i lokalnymi greckimi organizacjami zajmującymi się dziedzictwem. Poulios obecnie pracuje jako wykładowca na Hellenic Open University, a także wykłada w dorocznej szkole UNESCO. Jego zainteresowania badawcze obejmują ochronę dziedzictwa w połączeniu ze zrównoważonym rozwojem oraz zaangażowaniem społeczności lokalnych.

4 Poulios I., Discussing strategy in heritage conservation. Living heritage approach as an example of strategic innovation, Journal of Cultural Heritage Management and Sustainable Development, Vol. 4 No. 1, 2014, s. 16-34.

5 Laurajane Smith jest naukowczynią zajmującą się dziedzictwem i muzealnictwem, chociaż początkowo kształciła się jako archeolożka. Smith bada, w jaki sposób dziedzictwo funkcjonuje w świadomości społeczeństwa i jak kształtuje tożsamość indywidualną i zbiorową. Jest autorką wydanej w 2006 roku książki Uses of Heritage. Ukończyła studia magisterskie na University of South oraz studia doktoranckie na University of Sydney. Obecnie pracuje w Australian National University, pełniąc tam funkcję kierowniczki Centrum Dziedzictwa i Studiów Muzealnych. Jest redaktorką International Journal of Heritage Studies i wraz z Williamem Loganem współredaktorką serii książek „Key Issues in Cultural Heritage".

6 Smith L., Uses of Heritage, Londyn 2006, s. 299.

7 Poulios I., Discussing strategy in heritage conservation..., op. cit., s. 16-34.

8 Convention for the Safeguarding of the Intangible Cultural Heritage $(\mathrm{ICH})$.

9 Międzynarodowe Centrum Badań nad Ochroną i Konserwacją Dziedzictwa Kulturowego (ICCROM) uruchomiło w 2003 roku program dotyczący obszarów „żywego dziedzictwa” - Living Heritage Sites. Program miał na celu podkreślenie aktywnych możliwości działania dziedzictwa: ich rozpoznawalności i znaczenia dla współczesnego życia, w tym korzyści i zainteresowań ludzi oraz ich zdolności do ochrony zabytków. Zachowanie tych obszarów życia, które obejmują i wspierają różnorodne działania społeczno-kulturowe, uznano za równie ważne jak i samą historyczną tkankę. Od tego czasu, program ICCROM Living Heritage Sites ewoluował, integrując niektóre najnowsze osiągnięcia w dyskursie o dziedzictwie. 
przestrzeń. Poulios twierdzi ${ }^{10}$, że siła tej koncepcji tkwi właśnie w idei kontynuacji pierwotnej funkcji tkanki historycznej. Tę kontynuację definiuje dość szeroko, nazywając ją również społeczną ciągłością praktyk, tradycji i wiedzy wspólnoty. Poulios podkreśla, iż ów aspekt wspólnotowy jest kluczowy. Społeczność „rdzenna” jest siłą napędową i wykonawcą podstawowej roli konserwatorskiej, zaś zadaniem konserwatorów jako specjalistów jest oferowanie wsparcia i pomocy merytorycznej.

Następuje tym samym wyraźne przesunięcie punktu ciężkości - materia historyczna jest użytkowana przez określoną społeczność, a nie pozostaje tylko bezosobowym artefaktem, poddawanym jedynie natarczywym badaniom i ochronie. Gamini Wijesuriya ${ }^{11}$ w swoim raporcie dla Międzynarodowego Centrum Badań nad Ochroną i Konserwacją Dziedzictwa Kulturowego (ICCROM) z 2015 roku podkreśla, iż pod wieloma względami dotychczasowa ochrona dziedzictwa, nie stawiała czoła izolacji, jaką pociągnął za sobą proces "muzealizacji", mocno zakorzeniony w zachodnim systemie zarządzania zabytkami. Odpowiedzią na to jest właśnie scalenie dotychczasowych metod, jakie oferuje koncepcja „żywego dziedzictwa"12, poprzez ochronę zarówno tkanki historycznej jak i niematerialnych wartości przy zaangażowaniu lokalnych społeczności, użytkujących dany obiekt. Nie jest ona substytutem wcześniej opracowanych praktyk, stanowi raczej uzupełnienie współczesnych podejść do zarządzania dziedzictwem i ich zespolenie. „Żywe dziedzictwo” jest zatem modyfikacją owych dwóch istniejących wcześniej koncepcji (opartych na materiale i na wartościach), tym samym będąc elastyczną metodą, którą można dostosować do danej kategorii historycznej materii, rozwiązaniem, w którym beneficjentami są zarówno zabytki jak i społeczność.

W polskiej kulturze istnieje wyraźna tradycja zaangażowania wspólnoty parafialnej, na której spoczywa odpowiedzialność za opiekę nad świątynią. Warto wspomnieć w tym miejscu Mariana Korneckiego ${ }^{13}$, wybitny autorytet w zakresie praktyki konserwatorskiej drewnianych obiektów zabytkowych, według którego "był bowiem Dom Boży ośrodkiem kultu religijnego i widomym znakiem wspólnoty kulturowej mieszkańców, a poniekąd ich społecznej organizacji" ${ }^{\prime 14}$. Kościół na Harendzie nie jest zatem pod tym względem ewenementem. Można wręcz zaryzykować stwierdzenie, że to istniejąca ogólnopolska tradycja opieki lokalnej wspólnoty nad obiektem sakralnym od lat wpisuje się w zdefiniowany (stosunkowo niedawno) trend "żywego dziedzictwa”.

Jest to także zauważalne w historii harendziańskiego kościoła, gdyż o jego stan dbała przez ostatnie dekady lokalna parafia i kolejni proboszczowie. Lokalna wspólnota była (i w pewnym sensie pozostaje) różnorodnym zespołem mieszkańców, duchownych, podhalańskich rzemieślników, artystów i pasjonatów architektury drewnianej. Odnotowanie tych zależności poprzez analizę historii miejsca pozwoliło na opracowanie programu prac konserwatorskich ze świadomym zaangażowaniem w to lokalnej wspólnoty. Ważnym aspektem była współpraca proboszcza z zespołem konserwatorskim, w celu uniknięcia nieświadomych, często wynikających z troski o zabytek, oddolnych działań „pseudo-konserwatorskich”. Niejednokrotnie takie sytuacje doprowadzają do nieodwracalnych zniszczeń w substancji zabytkowej.

Planowana konserwacja kościoła św. Jana Apostoła i Ewangelisty wpisuje się zatem w ideę „żywego dziedzictwa", właśnie poprzez czynny udział mieszkańców i sympatyków miejsca w ochronę oraz użytkowanie zabytku, przy czynnym, merytorycznym wsparciu specjalistów.

10 Poulios I., Discussing strategy in heritage conservation..., op. cit., s. 16-34.

11 Gamini Wijesuriya jest architektem, specjalistą do spraw zarządzania dziedzictwem i posiada doktorat z archeologii. Jako Dyrektor ds. Konserwacji Wydziału Archeologii Sri Lanki (1983-2000) był odpowiedzialny za zarządzanie programem ochrony dziedzictwa kulturowego tego kraju. Był wówczas głównym regionalnym naukowcem w Departamencie Ochrony Nowej Zelandii (2001-2004), zajmującym się opracowywaniem naukowych i badawczych strategii ochrony. Wijesuriya był aktywnym członkiem ICOMOS, zajmując różne stanowiska od 1984 r., w 2003 r. Został wybrany na wiceprzewodniczącego Światowego Kongresu Archeologicznego (WAC). Jest autorem wielu publikacji na temat ochrony i zarządzania dziedzictwem kulturowym. Od 2004 roku jest zatrudniony w ICCROM, gdzie odpowiada za organizację szkoleń i działań związanych ze światowym dziedzictwem.

12 Wijesuriya G., Living Heritage: a summary, ICCROM, Rzym 2015.

13 Marian Kornecki (1924-2001), historyk sztuki, konserwator zabytków, od 1951 do 1991 roku związany z urzędem Wojewódzkiego Konserwatora Zabytków w Krakowie. Był autorem wielu publikacji naukowych poświęconych m.in. architekturze drewnianej, takich jak „Drewniane kościoły w Małopolsce Południowej”, Ossolineum, 1984; "Gotyckie kościoły drewniane na Podhalu”, Wydawnictwo Literackie, 1987.

14 Kornecki M., Drewniana architektura sakralna w Polsce: zagadnienie typów i form regionalnych w rozwoju historycznym, Ochrona Zabytków $1992,45 / 1-2$ (176-177), s. 8 


\section{Historia kościoła}

Kościół św. Jana Apostoła i Ewangelisty, pierwotnie funkcjonował jako kościół pod wezwaniem św. Anny, i był zlokalizowany we wsi Zakrzów w powiecie wadowickim. Na Harendę został przeniesiony w połowie XX wieku. Losy kościoła w Zakrzowie sięgają XIV wieku, kiedy zbudowano tam pierwszy obiekt sakralny niewielkich rozmiarów. Drewniana kaplica służyła lokalnej społeczności do końca XVI wieku, jej fatalny stan zmusił parafię do podjęcia decyzji o rozebraniu i budowie nowego kościoła. Stąd, w 1720 roku proboszcz stryszowski ks. Błażej Karpiński ukończył budowę nowego kościoła, pod tym samym wezwaniem, którego forma została zachowana do dzisiaj ${ }^{15}$. Istotne informacje na temat wystroju i wyposażenia kościoła zawiera księga wizytacyjna z 1748 r., z której wynika, że nie zmienił się on zasadniczo do czasu przeniesienia go na Harende ${ }^{16}$.

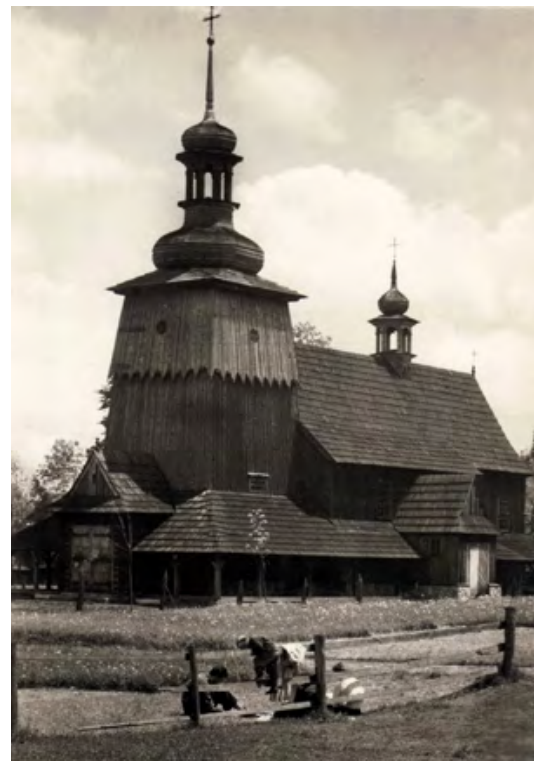

Ryc. 1. Kościół św. Anny w Zakrzowie, ok. 1968 r., fot. T. Jabrzemski, zbiory prywatne

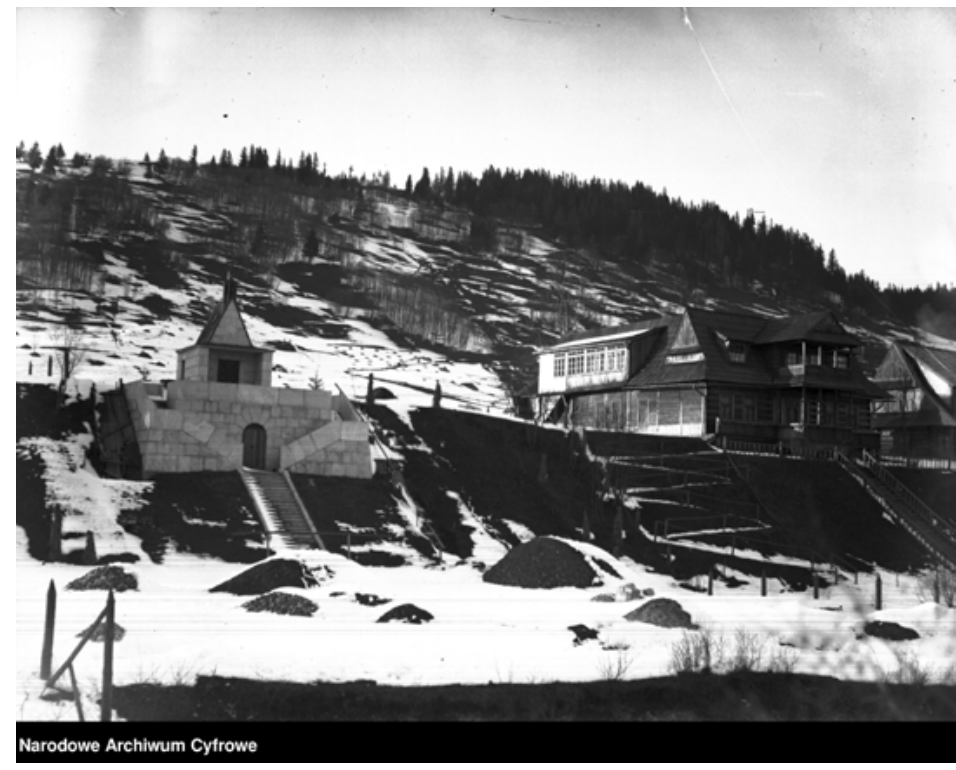

Ryc. 2. Widok ogólny willi „Harenda” i mauzoleum, ok. 1933. Źródło: NAC

Ze względu na zmiany administracyjne następujące w XIX wieku, liczba osób zamieszkujących wsie Zakrzów, Stronie i Leśnicę, znacznie się zwiększyła. W związku z tym rezydujący od 1909 r. w parafii ks. proboszcz Jan Bednarczyk, powziął plan budowy nowego, murowanego kościoła, który udało mu się zrealizować w latach 1932-35. Nowy, jednonawowy, murowany kościół zaprojektowany przez architekta Teodora Hoffmana przejął funkcję drewnianego kościółka, pozostawiając go nieużywanym i niszczejącym ${ }^{17}$.

Pomysł przeniesienia drewnianego kościółka na Harendę powstał w latach 40-tych XX w. Widoczna jest już wtedy kształtująca się "wspólnotowość", gdy ks. Jan Hyc i ks. Marduła, wraz z poparciem mieszkańców okolic między Zakopanem a Poroninem, rozpoczęli proces starania się o postawienie kościoła na Harendzie. Ze względu na wybrane miejsce, znajdujące się na wolnej części parceli Mauzoleum Kasprowicza, w 1947 r. poproszono

16 "Villa Zakrzow regalis ad capitaneatum Lanckoronensem pertinens, in Archidiaconatu et Officialatu Cracoviensi, Ducatu et Decanatu Zathoriensi sita. In hac villa est ecclesia quondam parochialis, successive autem extincto titulo parochiali, ecclesiae parochiali Stryszoviensi affiliata, tota lignea anno 1720 aedificata, nondum consecrata tituli S. Annae.", Księga wizytacyjna z 1748 r. (fol. 144-154) [za:] F. Lenczowski, O kościołach I parafiach w Stryszowie i Zakrzowie w diecezji krakowskiej, Nasza Przeszłość, s. 220.

17 F. Lenczowski, O kościołach..., op. cit. s. 223. 
o pomoc prof. Władysława Jarockiego ${ }^{18}$, zięcia Jana Kasprowicza ${ }^{19}$. Harenda od lat 20-tych pozostawała jednym z zakopiańskich salonów artystycznych ${ }^{20}$, właśnie ze względu na obecność Marii i Jana Kasprowiczów, mieszkających tam od 1924 roku. Po śmierci poety w 1926, Maria Kasprowiczowa kontynuowała tradycję, tworząc przestrzeń dla artystycznej bohemy, przygarniając młodych twórców i podtrzymując pamięć o zmarłym. Z inicjatywy Kasprowiczowej w 1933 w ogrodzie Harendy stanęło Mauzoleum Kasprowicza, zaprojektowane przez Karola Stryjeńskiego, zaś w 1950 parterową część domu przeznaczono na Muzeum Jana Kasprowicza. Muzeum w willi działa do dzisiaj, prowadzone przez Stowarzyszenie Przyjaciół Twórczości Jana Kasprowicza. Założona przez Kasprowiczową w 1964 organizacja podtrzymuje tradycję inkluzywnej, wspólnotowej Harendy ${ }^{21}$.

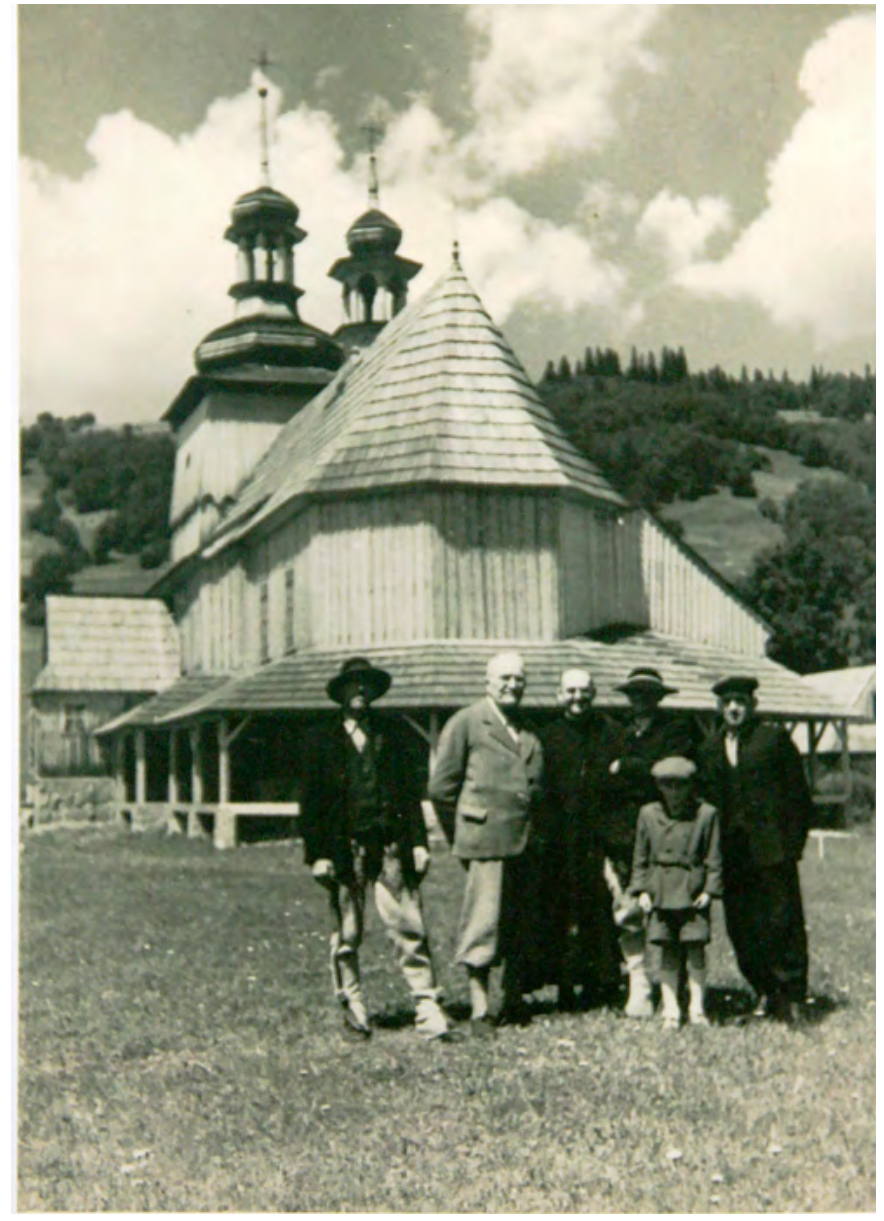

Ryc. 3. Władysław Jarocki na tle harendziańskiego kościółka

Źródło: fot. Zofia Weiss, zasoby Muzeum Jana Kasprowicza, katalog wystawy "Władysław Jarocki", Kraków-Zakopane 2015, str. 214.

Oddolna inicjatywa duchownych, mieszkańców oraz lokalnego środowiska artystycznego zaowocowała powstaniem Komitetu Budowy Kościoła na Harendzie, w imieniu którego profesor Jarocki po uzgodnieniach z Marią Kasprowiczową, zwrócił się do Wojewódzkiego Urzędu Konserwatorskiego o wybór jednego z dwóch

18 Władysław Jarocki (1879-1965) - malarz i architekt, absolwent Politechniki Lwowskiej oraz Akademii Sztuk Pięknych w Krakowie, początkowo działający w pracowni prof. Józefa Mehoffera, później pod kierunkiem prof. Leona Wyczółkowskiego. Odbywał podróże artystyczno-studialne do Włoch, Gruzji i innych krajów, by w 1911 zacząć dzięki przyjaźni z Janem Kasprowiczem coraz więcej czasu spędzać na Podhalu. Po wojnie pracował jako pedagog na Politechnice Lwowskie oraz, w Państwowej Szkole Sztuk Zdobniczych i Przemysłu Artystycznego we Lwowie, później jako profesor nadzwyczajny ASP w Krakowie był dziekanem Wydziału Malarstwa oraz Wydziału Rzeźby, jak również prorektorem Akademii. W 1920 r. poślubił córkę Jana Kasprowicza - Annę, co jeszcze mocniej zbliżyło go do Harendy. Przyczynił się do powstania domu plenerowego Akademii Sztuk Pięknych na Harendzie, który został przez nią zakupiony obok domu Kasprowicza w 1927 r. Był również zaangażowany w powstanie Mauzoleum Kasprowicza. W latach 1947-50 aktywnie zaangażował się w relokację kościoła z Zakrzowa na Harendę, wykonując renowację polichromii ściennej. Do końca życia związany z Harendą i Podhalem.

19 F. Lenczowski, O kościołach..., op cit, s. 212-224.

20 M. Krupa, Kroniki Zakopiańskie, Wołowiec, 2015, s. 214

21 M. Krupa, op. cit, s. 214. 
kościółków drewnianych - Zakrzowa lub Komorowic - nadających się do przeniesienia. Wybrano drewniany zakrzowski kościół św. Anny i w 1948 r. rozpoczęto składanie budowli w nowym miejscu. Do trwającego niecałe trzy lata procesu nadzorowanego przez prof. Jarockiego czynnie przyczynili się mieszkańcy Harendy. Od 1982 świątynia funkcjonuje jako kościół parafialny dla obszaru Harenda w Zakopanem i jest, wraz z Mauzoleum i Muzeum Jana Kasprowicza, dopełnieniem założenia będącego wspomnieniem po poecie.

\title{
Architektura drewniana i problemy konserwatorskie
}

\begin{abstract}
W historycznym krajobrazie Polski szczególne miejsce zajmuja światynie, będace nie tylko czołowymi osiagnięciami ciesielstwa, ale również istotnymi elementami struktur osadniczych, zarówno w fizycznym sensie - jako ich dominanty architektoniczne - jak i w wymiarze ideowym ${ }^{22}$.
\end{abstract}

\section{Marian Kornecki}

Konserwacja i ochrona polskiej architektury drewnianej jest znanym i szeroko opisywanym w literaturze przedmiotu tematem. Jerzy Szałygin zwraca szczególną uwagę na fakt, jak istotną częścią architektury drewnianej w Polsce jest architektura sakralna ${ }^{23}$. Szałygin pisze: „Drewniana architektura i budownictwo - ich walory i powolny zanik - dostrzeżone zostały już w końcu XIX i na początku wieku XX, kiedy to nie tylko zaczęto inwentaryzować drewniane obiekty, ale również dbać o nie oraz upowszechniać wiedzę o ich znaczeniu dla polskiego dziedzictwa"24. Przykładem jednej z pierwszych kompleksowych prac inwentaryzacyjnych była seria zeszytów Feliksa Kopery i Leonarda Lepszego ${ }^{25}$. W latach 1913-1916 wydali zeszyty, w których opisali 59 obiektów, w tym kościoły i cerkwie. Zbiór zeszytów pozostaje istotnym punktem wyjścia do badań nad małopolską architekturą drewnianą ${ }^{26}$. Zasłużonymi badaczami i propagatorami ochrony, inwentaryzacji i konserwacji architektury drewnianej w latach powojennej Polski XX wieku byli historycy sztuki i konserwatorzy zabytków, tacy jak wspominany wcześniej Marian Kornecki, Tadeusz Chrzanowski ${ }^{27}$ czy Ryszard Brykowski ${ }^{28}$. Ich studia i prace położyły podwaliny pod obecnie stosowaną powszechnie sztukę konserwacji i ochrony tych unikatowych zabytków.

Podczas gdy Kopera zauważa ignorancję i brak poszanowania i doceniania wartości polskiej architektury drewnianej pod koniec XIX wieku ${ }^{29}$, Szałygin zwraca uwagę na późniejsze, narastające w społeczeństwie przekonanie o "nieprzebraniu zasobów” drewnianej architektury, wynikające z dużej ilości odkrytych i wpisywanych do rejestru obiektów, dające fałszywe poczucie bezpieczeństwa i braku konieczności ochrony ${ }^{30}$. Są to interesujące obserwacje dotyczące zmian w tendencjach, zwłaszcza w kontekście współczesnych działań konserwatorskich, w których można zaobserwować świadomy powrót do aktywnej konserwacji polskiej architektury drewnianej, ponowne zauważanie jej wartości i ulotności.

22 Kornecki M., Drewniana architektura sakralna w Polsce: zagadnienie typów i form regionalnych w rozwoju historycznym, Ochrona Zabytków $1992,45 / 1-2$ (176-177), s. 7-31.

23 J. Szałygin, Dziedzictwo drewnianej architektury w Polsce, "Ochrona Zabytków”, 2013, 66/1-4 (260-263), s. 281.

24 J. Szałygin, Dziedzictwo drewnianej..., op. cit. s. 283.

25 Mowa o trzytomowej serii „Kościoły drewniane Galicyi Zachodniej” wydanej w języku polskim i częściowo niemieckim, autorstwa Feliksa Kopery i Leonarda Lepszego z fotografiami Stefana Wąsa.

26 M. Wilkosz-Mamcarczyk, Ogrodowe założenia sakralne w wiejskich krajobrazach powiatu wadowickiego, Czasopismo Techniczne Politechniki Krakowskiej, 2-A/2012 7/109, s. 316.

27 Tadeusz Chrzanowski (1926- 2006), historyk sztuki, literat, fotograf, profesor Politechniki Krakowskiej i Katolickiego Uniwersytetu Lubelskiego. Był współautorem wspólnie tekstu „Drewno w polskiej architekturze i rzeźbie drewnianej”, wspólnie z K. Piwockim, PAN, Instytut Sztuki, Ossolineum, 1981.

28 Ryszard Brykowski (1936-2017), historyk sztuki, profesor nauk humanistycznych, specjalista w zakresie drewnianej architektury sakralnej, historii sztuki, inwentaryzacji i konserwacji zabytków. W szczególności zajmował się sakralną architekturą drewnianą cerkiewną Pokucia i Huculszczyzny. Był autorem wielu publikacji, takich jak m.in. „Drewniane kościoły w Małopolsce Południowej” (1984); "Sztuka Rumunii” wspólnie z T. Chrzanowskim, M. Korneckim (1979) - wydanych przez Zakład Narodowy im. Ossolińskich we Wrocławiu.

29 Kopera F., Ze wspomnień konserwatora, Ochrona Zabytków, 1949, 2/2 (6), s. 84-87.

30 J. Szałygin, Dziedzictwo drewnianej..., op. cit. s. 286. 


\section{Forma}

Przeniesienie budowli na Harendę było równoznaczne z koniecznością wprowadzenia zmian strukturalnych, związanych zarówno z dopasowaniem budynku do nowej lokalizacji i kontekstu jak i wymianą zniszczonych elementów.

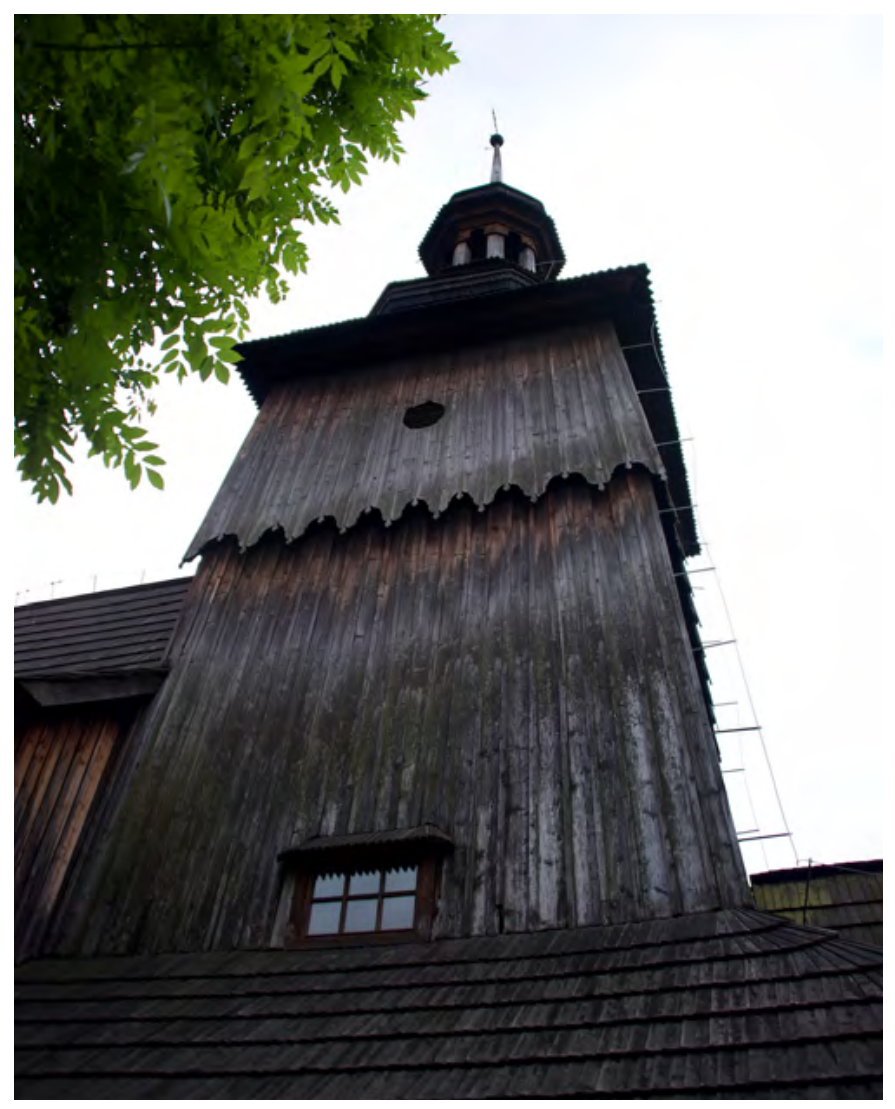

Ryc. 4. Widok na wieżę/dzwonnicę, fot. M. Petri

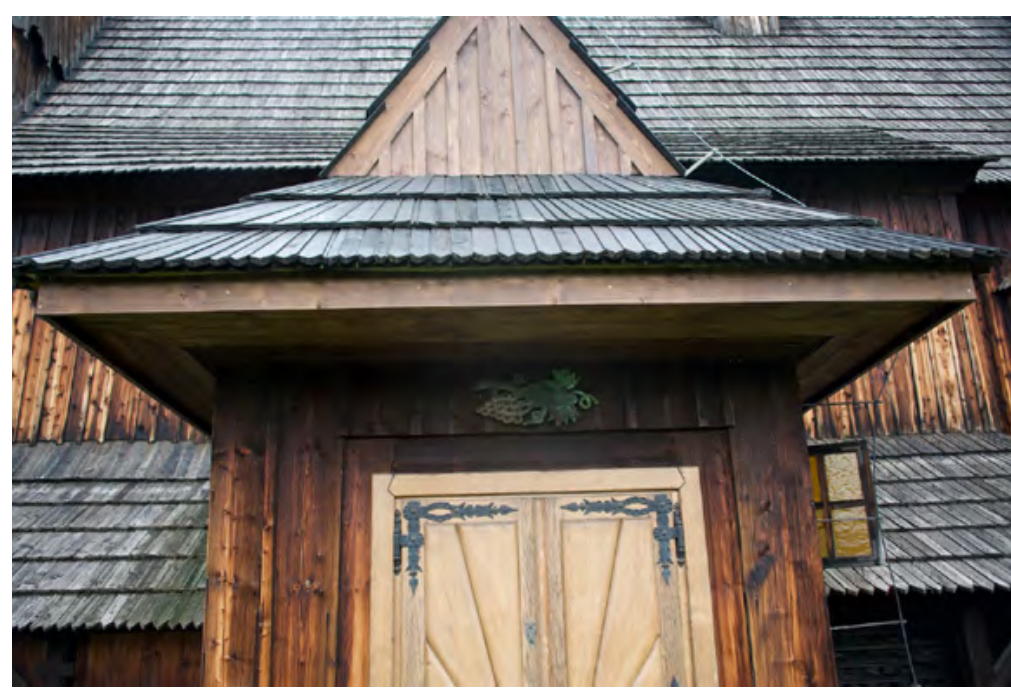

Ryc. 5. Wejście od strony południowej, widoczne elementy podhalańskie, fot. M. Petri

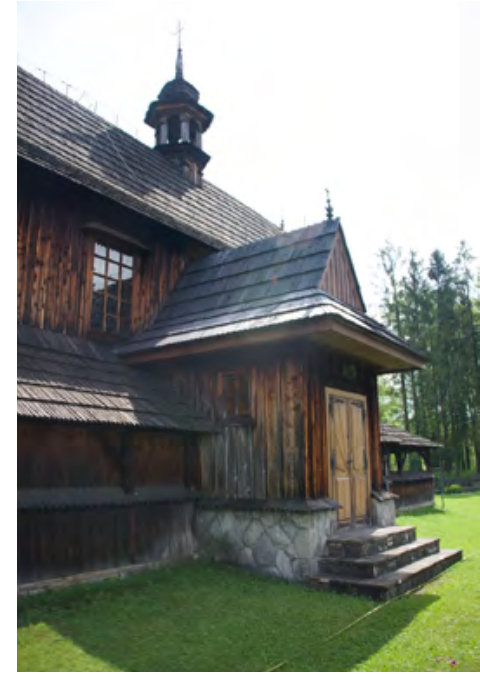

Ryc. 6. Podmurówka i soboty, fot. M. Petri 
Kościół posiada typowy układ jednonawowy o drewnianej konstrukcji zrębowej z oddzieloną częścią prezbiterium z wielobocznym zamknięciem, z zakrystią oraz wieżą umiejscowioną w części wejściowej kościoła. Ściany nawy głównej oraz prezbiterium są oszalowane pionowo, łączone węgłami słowiańskimi i kryte deskowaniem z wykończeniem listwowym. Zwieńczona zdobną sygnaturką wieża (prawdopodobnie pierwotnie funkcjonująca jako dzwonnica) stanowi dominantę wysokościową jako najwyższy element budynku.

Ze względu na zły stan zachowania, część desek i listewek została wymieniona podczas składania budowli w 1948. Podczas relokacji jej wnętrze zostało obudowane i stanowi przedłużenie kruchty ${ }^{31}$.

Kościół na Harendzie stanowi interesujący przykład ludowej ciesiołki, wzbogaconej o regionalne elementy podhalańskie. Za wyjątkiem wejść do kościoła, będących ryzalitami wystającymi poza obręb bryły, jest ona otoczona niskim zadaszonym, jednospadowym podcieniem w formie krużgankowej, zwanym "sobotami" dobudowanymi w okresie relokacji kościoła. "Soboty”, będące typowym rozwiązaniem podhalańskim (choć występującym również w innych regionach Polski) to jeden z kilku elementów regionalnych wprowadzonych do zakrzowskiej świątyni. Inne to zastąpienie blachy dachowej gontem, zastosowanie typowych dekoracji góralskich na belkach oraz drzwiach wejściowych, a także wspominana wcześniej podmurówka, wykonana z obrobionych ciosów kamiennych oraz z kamieni łamanych. Te zabiegi wynikały nie tylko z konieczności wymiany zniszczonych elementów, ale właśnie z potrzeby udomowienia zabytku, usadowienia go w nowym, zakopiańskim kontekście.

W latach 50-tych pracom rewaloryzacyjnym zostało poddane również wnętrze kościoła, zaczynając od wykonania przez Władysława i Annę Jarockich renowacji polichromii ściennej oraz dekoracji malarskich na belkach. Jarocki wykonał aranżację całego wnętrza w stylu regionalnym, odnawiając zniszczoną polichromię ścienną w stylu późnobarokowym z 1719 r. autorstwa malarza cechowego o nazwisku Sabatowski ${ }^{32}$. Namalował też obrazy ołtarzowe z przedstawieniami św. Jana Ewangelisty do ołtarza głównego, Narodzenia oraz Matki Boskiej Harendziańskiej do ołtarzy bocznych. Ustawiony centralnie barokowy ołtarz główny z obrazem Jarockiego został przywieziony z Książa Wielkiego, gdyż oryginalny uległ zniszczeniu. Strop prezbiterium zdobi przedstawienie Koronacji Matki Boskiej, chór - św. Cecylia z muzykującymi aniołkami. Na przestrzeni lat kościół wzbogacił się również o dzieła sztuki regionalnej, między innymi o krucyfiks z drewna gruszkowego autorstwa Macieja Marduły, czy rzeźbę Świętej Trójcy autorstwa górala Klusia Harendzkiego z ok. 1851 r., a także obrazy i płaskorzeźby ludowe.

W latach 70-tych kościół był poddany drobnym pracom remontowym, takim jak zabezpieczenie niszczonych elementów, przeprowadzenie odwodnienia czy wzmacnianie konstrukcji.

\section{Stan zniszczeń}

Pomimo dotychczasowego zaangażowania parafii w proste prace konserwatorskie i zapobiegawcze, takie jak odczyszczanie drewna, działanie czynników zewnętrznych sprawiło, iż obecny stan obiektu nie może zostać zaklasyfikowany jako dobry.

Kościół na Harendzie poddano badaniom historyczno-architektonicznym w interdyscyplinarnym zespole ${ }^{33}$ - zaowocowało to rzetelną dokumentacją, w której skład wchodziła inwentaryzacja architektoniczna zewnętrza i wnętrza, ekspertyza konstruktorska, mykologiczna oraz ekspertyza techniczna systemu odgromowego ${ }^{34}$. Szczegółowe badania konserwatorskie zabytkowych polichromii wnętrza objęły swoim zakresem badania fizyko-chemiczne nawarstwień polichromii ściennej, ołtarza głównego oraz ołtarzy bocznych, obrazu "Chrystus Król" na podobraziu drewnianym.

31 J. Rogulska-Cybulska, Kościótek na Harendzie, Tygodnik Powszechny, 1950, nr 50/299, s. 8.

32 Nazwisko to podaje J. Rogulska-Cybulska, op. cit., s. 8.

33 Tymcik E., Banasik-Petri K., Dokumentacja konserwatorsko-architektoniczna dla drewnianego, zabytkowego kościoła pw. Św. Jana Apostoła i Ewangelisty na Harendzie, w tym T. 1 i T. 2, Kraków 2020, mps w posiadaniu autorek.

34 Zastosowane metody badawcze to: kwerenda archiwalna, wykonanie sond stratygraficznych ilustrujących ilość i rodzaj nawarstwień, ujawniających ich pierwotną kolorystykę oraz technikę wykonania, analiza w świetle białym i świetle UV - wykonanie fotografii ukazujących zakres przemalowań warstwy malarskiej, analiza chemiczna pobranych próbek pigmentów warstw malarskich, w tym wykonanie przekrojów poprzecznych wybranych fragmentów dekoracji malarskiej, analiza mykologiczna pobranych próbek powietrza oraz wymazów z drewna identyfikacja makroskopowa i mikroskopowa próbek. Wyniki zawiera Analiza próbek warstw malarskich z kościoła pw. św. Jana Apostoła i Ewangelisty na Harendzie, Kraków, 2020, [w:] E. Tymcik, Program prac konserwatorskich dla zabytkowego, drewnianego kościoła pw. Św. Jana Apostoła i Ewangelisty na Harendzie- tom I, Aneks nr I, Kraków 2020, mps w posiadaniu autorki. 
Elewacje zewnętrzne kościoła uległy degradacji pod wpływem czynników atmosferycznych przede wszystkim takich jak duże amplitudy temperatur rocznych i dobowych, silne nasłonecznienie i długotrwałe opady deszczu czy śniegu. Nieodłącznym ich skutkiem jest biodeterioracja drewna, związana z niszczeniem materii zabytkowej przez drobnoustroje (glony, mchy, porosty, grzyby) które atakują mocno zawilgocone powierzchnie, wytwarzając produkty korozji. Stan obecny jest również bezpośrednio związany z faktem, iż drewniane deski elewacyjne pochodzące sprzed okresu przeniesienia budowli nie były poddane pracom renowacyjnym przez kilkadziesiąt lat. Zmieniły całkowicie swój pierwotny wygląd, pociemniały, uległy lokalnym przebarwieniom, w tym zszarzeniu, związanym z działalnością zgnilizny jasnej oraz pleśniowej, które wpływają na obniżenie własności wytrzymałościowych drewna.

Ze względu na umiejscowienie budynku względem stron świata na poszczególnych elewacjach zauważalne są zniszczenia o odmiennym charakterze. Ściana północna, najbardziej narażona na zawilgocenia jest zainfekowana sinizną wtórną i pokryta nalotem mchu, natomiast ściana południowa jest mocno przesuszona, deski elewacji uległy lokalnym rozszczepieniom czy spękaniom.

Więźba dachowa przedstawia umiarkowany stan zachowania, wynikający z przeprowadzonych napraw pokrycia dachowego, co zabezpieczyło wnętrze przed zalewaniem wodą opadową w ciągu ostatnich kilkudziesięciu lat. Należy jednak zwrócić uwagę na lokalne zniszczenia wywołane występującą korozją biologiczną oraz infekcję spowodowaną działalnością owadzich szkodników drewna. Pokrycie dachowe wykonane w czasie relokacji z tzw. gontu dubeltowego uległo zniszczeniom w zależności od usytuowania na połaci dachowej. Występujące uszkodzenia w postaci pęknięć, zdeformowań czy porostów mchami i zgrzybienia, również są uzależnione od strony świata i bezpośrednio powiązane ze zmiennymi warunkami atmosferycznymi. Zauważalne są miejscowe naprawy i uzupełnienia, szczególnie na połaciach "sobót".

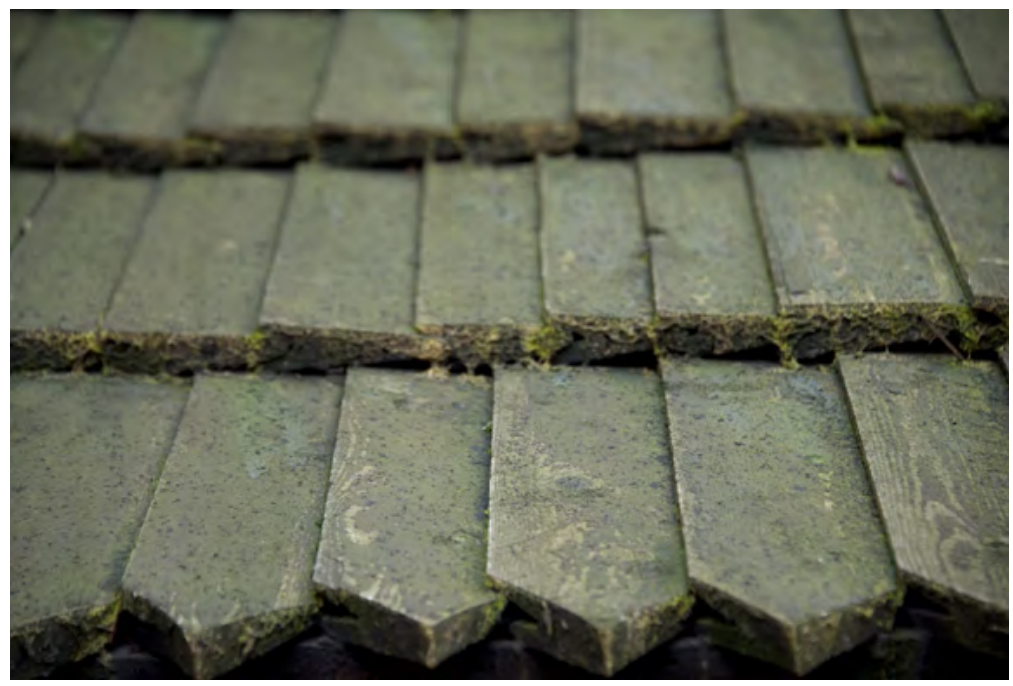

Ryc. 7. Nalot mchu na goncie elewacji północnej, fot. M. Petri

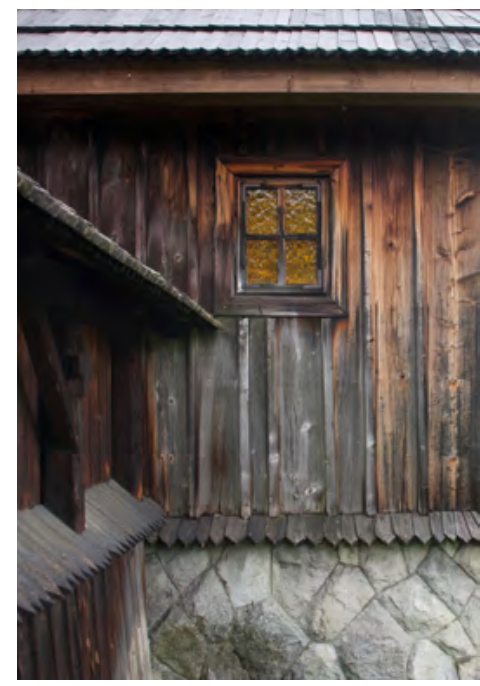

Ryc. 8. Przesuszenia i spękania na elewacji południowej, fot. M. Petri

\section{Proponowane prace konserwatorskie}

Ze względu na to, iż zniszczenia w głównej mierze dotykają drewnianej tkanki historycznej, proponowane prace konserwatorskie dotyczą głównie drewnianych elementów konstrukcyjnych kościoła, elewacji zewnętrznych, podcieni, sygnaturek oraz pokrycia dachowego. Zakres planowanych zabiegów obejmie przywrócenie stabilności konstrukcyjnej budowli poprzez wzmocnienie strukturalne naruszonych elementów oraz wymianę tych całkowicie uszkodzonych biologicznie, pochodzących z więźby dachowej, konstrukcji wieży czy szalunku elewacji.

Techniczne i estetyczne prace konserwatorskie przy elementach drewnianych powinny objąć następujące zabiegi: oczyszczenie powierzchni, dezynfekcję, dezynsekcję, uzupełnienie ubytków i sklejenie pęknięć odpowiednio 
dobranymi środkami, impregnację drewna środkiem biobójczym oraz hydrofobizację właściwym preparatem. Deski elewacyjne należy zatem wyczyścić poprzez mechaniczne (strumieniowo-ścierne) lub chemiczne usunięcie nagromadzonych zanieczyszczeń, zmurszeń i zagrzybień. Po głównych pracach budowlanych konieczne jest zaimpregnowanie drewna powłokami ochronnymi i powłokotwórczymi. Przy nieuniknionej wymianie elementów elewacji, które uległy nieodwracalnemu zniszczeniu należy zastosować deski drewniane modrzewiowe, montowane bezpośrednio do ściany konstrukcyjnej w układzie pionowym, na gwoździach ciesielskich czarnych - identycznie z istniejącymi deskami w kształcie i wielkości. Żeby zachować dotychczasową formę, pomiędzy deskami należy zastosować listwowanie. Rekonstruowane elementy powinny zostać tak dobrane, aby udało się scalić je estetycznie z zachowanymi, zabytkowymi elementami obiektu.

Analogicznie należy postępować przy wymianie i odczyszczaniu połaci dachowych - uszkodzonych gontów. Pokrycie dachowe wykonane z gontu powinno zostać oczyszczone mechanicznie, zdezynfekowane i ustabilizowane poprzez właściwą impregnację i hydrofobizację. Analiza stanu zachowania pokrycia wykazała ok. $50 \%$ degradację gontów na dachu kościoła i podcieni. W przypadku konieczności wymiany uszkodzonych elementów należy położyć gont tzw. szczypany, czyli łupany ręcznie, z bezsęcznych odcinków pnia, z drewna modrzewiowego. Gont łupany ze względu na naturalną strukturę drewna jest bardziej odporny na warunki atmosferyczne od gontu ciętego.

Ze względu na przenosiny kościoła z powiatu wadowickiego na Podhale, a w konsekwencji zmiany w postaci dodania elementów dekoracyjnych, spowodowane regionalizacją formy, zadecydowano o zaproponowaniu prac konserwatorskich w myśl definicji autentyczności zapisanej w dokumencie z Nara ${ }^{35}$. Mowa w nim o konieczności rozumienia autentyzmu ściśle w danym kontekście, respektując wartości kulturowe i społeczne określonego państwa lub rejonu ${ }^{36}$. Należy zatem podkreślić wagę najważniejszego zalecenia - aby wymieniać jak najmniejszą ilość istniejącej substancji i zachować jak największą ilość oryginalnej tkanki budowli. Ponadto, prace konserwatorskie i budowlane muszą zostać przeprowadzone zgodnie z tradycyjną, lokalną sztuką ciesielską. Tylko dzięki temu zachowana zostanie wartość, integralność i ciągłość dziedzictwa.

Wymienione zalecenia zostaną przekazane osobom odpowiedzialnym za kościół użytkującym go na co dzień, aby dopuścić ich do świadomej kontynuacji wspólnej ochrony zabytku. W ten sposób program konserwatorski wpisuje się we współczesną definicję koncepcji „żywego dziedzictwa”, oferując użytkownikom merytoryczne wytyczne dotyczące opieki i konserwacji, by kościół nadal mógł spełniać swoją funkcję. Wspólnota zostaje wzbogacona o specjalistyczną wiedzę i praktyczną pomoc, co umacnia więź z zabytkiem i zapewnia jego bezpieczeństwo. Ów aspekt społeczno-edukacyjny warto podkreślić i rozpowszechnić.

\section{Podsumowanie}

Konserwacja kościoła parafialnego św. Jana Apostoła i Ewangelisty na Harendzie w Zakopanem, to kolejny etap w historii świątyni. Proponowane prace konserwatorskie dotyczą zarówno zewnętrza jak i wnętrza ${ }^{37}$ zabytku. Klasyczna idea konserwacji „material-based” („oparta na materiale”) umożliwia rzetelne przygotowanie planowanych prac konserwatorskich, uniknięcie przypadkowości rozwiązań technologicznych i zachowanie historycznej tkanki, natomiast idea „żywego dziedzictwa” pozwoli lokalnej społeczności otoczyć zabytek profesjonalną opieką, w oparciu o wytyczne specjalistów.

Promowanie umiejętnej i świadomej ochrony lokalnych zabytków oraz angażowanie w to nie tylko specjalistów i władz konserwatorskich, ale także wspólnot parafialnych, które w myśl polskiej tradycji otaczają obiekty sakralne opieką, wpisuje się bezpośrednio w omawianą wcześniej szczegółowo koncepcję „żywego dziedzictwa”.

Takie podejście pozwala, aby beneficjentami i uczestnikami procesu konserwacji było społeczeństwo, a w konsekwencji otacza ochroną dziedzictwo materialne, wspierając oddolne inicjatywy oraz podtrzymuje kontynuację funkcjonowania dziedzictwa kulturowego. Zaangażowanie wspólnoty parafialnej w konserwację

35 Dokument z Nara został utworzony na konferencji ICCOROM, ICOMOS i UNESCO w japońskim mieście Nara w 1994 r.

36 The Nara Document on Authenticity (1994), www.icomos.org/charters/nara-e.pdf (dostęp: 04.06.2021)

37 Szczegółowe wyniki ekspertyz zawiera Dokumentacja konserwatorsko-architektoniczna dla..., op. cit. w posiadaniu autorek. Artykuł autorstwa autorek niniejszego tekstu poświęcony szczegółowym pracom konserwatorskim dotyczącym wnętrza jest w trakcie przygotowań do publikacji. 
jest bezpośrednio związane z pielęgnacją identyfikacji mieszkańców z miejscem i utrzymywaniem relacji z zabytkiem. Tym samym, taka strategia może uchronić wiele miejsc o wybitnej architekturze, które zatracają swój lokalny, żywy charakter stając się nienaturalnie konserwowanym skansenem dawnej architektury.

\section{Bibliografia}

[1] Araozb G., Tendencje dziedzictwa dziś i jutro - z perspektywy ewolucji filozofii i teorii konserwacji, Wiadomości Konserwatorskie, 43/2015, s. 9-17.

[2] Brykowski R., Kornecki M., Drewniane kościoty w Matopolsce Południowej, Ossolineum, 1984.

[3] Chrzanowski T., Piwocki K., Drewno w polskiej architekturze i rzeźbie ludowej, PAN, Instytut Sztuki, Ossolineum, 1981.

[4] Golka M., Podróże, zamyślenia, aluzje, Oficyna Naukowa, Warszawa, 2016.

[5] Kopera F., Kościoły drewniane Galicyi Zachodniej. Serya 1 = Die Holzkirchen Westgaliziens. I. Serie, Wydawnictwo Grona Konserwatorów Galicyi Zachodniej, Kraków 1913.

[6] Kopera F., Kościoły drewniane Galicyi Zachodniej. Serya 1, zeszyt 2 = Die Holzkirchen Westgaliziens. I. Serie, II Heft, Wydawnictwo Grona Konserwatorów Galicyi Zachodniej, Kraków 1915.

[7] Kopera F., Lepszy L., Kościoły drewniane Galicyi Zachodniej. Serya 1, zeszyt 3 = Die Holzkirchen Westgaliziens. I. Serie, III Heft, Wydawnictwo Grona Konserwatorów Galicyi Zachodniej, Kraków 1916.

[8] Kopkowicz F., Ciesielstwo polskie. Arkady, Warszawa 2009.

[9] Kornecki M., Drewniana architektura sakralna w Polsce: zagadnienie typów i form regionalnych w rozwoju historycznym, Ochrona Zabytków, 1992, 45/1-2 (176-177), s. 7-31.

[10] Kobyliński Z., Czym jest, komu jest potrzebne i do kogo należy dziedzictwo kulturowe?, MAZOWSZE Studia Regionalne, nr 7/2011, s. 21-47.

[11] Lenczewski F., O kościołach i parafiach w Stryszowie i Zakrzowie w diecezji krakowskiej, Nasza Przeszłość: studia z dziejów Kościoła i kultury katolickiej w Polsce, T. 45: 1976, s. 191-233.

[12] Poulios I., Discussing strategy in heritage conservation. Living heritage approach as an example of strategic innovation, Journal of Cultural Heritage Management and Sustainable Development, Vol. 4 No. 1 (2014), s. 16-34.

[13] Poulios I., The Past In The Present: A Living Heritage Approach - Meteora, Greece, Ubiquity Press, Londyn 2014.

[14] Rogulska-Cybulska J., Kościótek na Harendzie, Tygodnik Powszechny, 1950, nr 50/299, s. 8.

[15] Schatt-Babińska K., Europocentryczne i dalekowschodnie spojrzenie na wartość autentyzmu zabytku - dokument z Nara jako próba pogodzenia odmiennych poglądów, Gdańskie Studia Azji Wschodniej, 2016, Zeszyt 10, s. 28-40.

[16] Smith L., Uses of Heritage, Routledge, Londyn 2006.

[17] Szałygin J., Dziedzictwo drewnianej architektury w Polsce, Ochrona Zabytków, 2013, nr 66/1-4 (260-263), s. 281-298.

[18] Szmygin B. (red.), Systemy wartościowania dziedzictwa. Stan badań i problemy, Politechnika Lubelska i Polski Komitet Narodowy ICOMOS, Lublin - Warszawa 2015.

[19] Wieczorek K., Konserwacja drewnianych struktur architektonicznych - nowe warunki, potrzeby i perspektywy, Wiadomości Konserwatorskie, 2013, vol. 36, s. 29-37.

[20] Wijesuriya G., Past is in the Present: Perspectives in Caring for Buddhist Heritage, Conservation of Living Religious Heritage, ICCROM Conservation Studies 3 ICCROM, Rzym 2005, s. 31-43.

[21] Wijesuriya G., Conserving Living Taonga: The Concept of Continuity. W: red. nauk. Sully D., Decolonising Conservation-Caring for Maori Meeting Houses outside New Zealand, Left Coast Press, Walnut Creek, California, 2007, s. 59-69.

[22] Wijesuriya G., Living Heritage: a summary, ICCROM, Rzym 2015.

[23] Wilkosz-Mamcarczyk M., Ogrodowe założenia sakralne w wiejskich krajobrazach powiatu wadowickiego, Czasopismo Techniczne Politechniki Krakowskiej, 2-A/2012 7/109, s. 315-330. 